\title{
AGGREGATE LITIGATION CASES IN BRAZIL: NOTEWORTHY CONSIDERATIONS ON THE AGGREGATION OF CASES, CLASS ACTIONS AND BINDING PRECEDENTS IN LITIGATIONS PURSUANT TO THE NEW CPC/2015
}

\author{
CASOS REPETITIVOS NO BRASIL: CONSIDERAÇÕES SOBRE A AGREGAÇÃO DE QUESTÕES, \\ AÇÕES COLETIVAS E PRECEDENTES VINCULANTES NO NOVO CPC / 2015
}

\begin{abstract}
Hermes Zaneti Jr ${ }^{1}$
Pós-Doutorado em Direito pela Università degli Studi di Torino (2014). Mestre e Doutor em Direito pela Universidade Federal do Rio Grande do Sul (2005), área de concentração Direito Processual. Doutor em Direito pela Università degli Studi di Roma Tre (2014), área de concentração Teoria do Direito. Professor do Programa de PósGraduação Strictu Sensu da Universidade Federal do Espírito Santo (Mestrado). Membro da Associação Internacional de Direito Processual, do Instituto Ibero-americano de Direito Processual e do Instituto Brasileiro de Direito Processual. Promotor de Justiça no Estado do Espírito Santo (2006/MPES). E-mail: hermeszanetijr@gmail.com
\end{abstract}

Recebido em:17/07/2019

Aprovado em:16/03/2020

\begin{abstract}
Brazilian law is experiencing intense transformation. Civil Procedural Law has incorporated the aggregate litigation model of adjudication as means to cope with the increasingly large volume of lawsuits, currently, more than 110 million cases. The aggregate litigation technique combines cases of identical procedural or subject matter nature and submits them to a joint trial by filing a chosen leading case. This adjudicating technique is applicable to ongoing lawsuits of individual or class nature, pursuant to the CPC, which foresees two different scenarios: the aggregate claims (IRDR) and the aggregate appeals of either infra constitutional or constitutional matter. For a fair process to be ensured, the relationship between aggregate litigation and class actions cases, as well as the relationship between aggregate litigation and the establishment, application and overruling of binding precedents require the development of appropriate techniques and tools.
\end{abstract}

Keywords: Aggregate Litigation - Class Actions - Binding Precedents - CPC/2015

RESUMO: O direito brasileiro está passando por intensa transformação. O Direito Processual Civil incorporou o modelo agregado de julgamento de litígios como forma de lidar com o crescente volume de ações judiciais, atualmente, com mais de 110 milhões de casos. A técnica dos casos repetitivos (litígios agregados) combina questões de natureza comum em direito material ou direito processual e os submete a um julgamento conjunto, julgando um caso-teste escolhido. Essa técnica de julgamento é aplicável a processos em andamento de natureza individual ou coletiva, de acordo

\footnotetext{
${ }^{1}$ Prof. Dr. Hermes Zaneti Jr. is tenured Professor of Civil Procedure and General Theory of Procedural Law at the Federal University of Espirito Santo, Brazil. Public Prosecutor at the State of Espirito Santo, Brazil. Member of the International Association of Procedural Law (IAPL), the Iberian-American Institute of Procedural Law (IIDP) and the Brazilian Institute of Procedural Law (IBDP). This article was translated by Elisa S. Townsend (dual BrazilianAmerican Citizen with Business \& Law Degrees). Lecture given in Lyon at the Brazil-France Meeting, held at Université Lyon III - Jean Moulin. I would like to thank Professors Loïc Cadiet and Frédérique Ferrand for the kind reception and Professor Yves Strickler for the instigating debates.
}

Revista de Direito Brasileira | Florianópolis, SC | v. 24 | n. 9 | p.428-443 | Set./Dez. 2019 
com o CPC, que prevê dois cenários diferentes: a agregação de questões mediante um incidente (IRDR) e a agregação de recursos sobre questões infra-constitucionais ou constitucionais. Para garantir um processo justo, o relacionamento entre litígios agregados e as ações coletivas, bem como o relacionamento entre litígios agregados e o estabelecimento, aplicação e superação de precedentes vinculantes, requer o desenvolvimento de técnicas e ferramentas apropriadas.

Palavras-chave: Agregação de Litígios - Processo Coletivo - Precedentes Vinculantes CPC/2015.

SUMMARY: Introduction: the relationship between legal traditions; 1 Aggregate Litigation: the aggregate claims (IRDR) and aggregate appeals (REER); 1.1 Historical precursors, inspiration and ideology; 1.2 Collective litigation: the formation of the opt-out and the opt-in groups; 1.3 Description of the Aggregate Claims Procedure and the Rules that are common to the Aggregate Appeals; 2 Aggregate Litigation and Class Actions; 3 Aggregate Litigation and Binding Precedents. Conclusions.

\section{INTRODUCTION: THE RELATIONSHIP BETWEEN LEGAL TRADITIONS}

A mining company builds a dam to deposit the sludge produced by its activity that is noncompliant with local regulations. The dam breaks, causing the biggest environmental disaster in Latin America, one of the largest in the world. People die, the largest river in the region turns into a sea of ore-toxic mud, decimating fish, animals and vegetation in the area. The now contaminated river water used to be the sole source of sustenance to more than 500,000 people who remain deprived of water for almost ten days. The result of this was civil chaos. The population, divested of water for basic needs such as hygiene and cooking, was forced to wait in long lines for the disbursement of rationed drinkable water.

In addition to the widespread damage to the environment that generates class actions to redress and indemnify, to the criminal cases that address the loss of human lives, and to the administrative fines, thousands of other individual lawsuits were filed on behalf of those living in cities that were impacted by water shortages requesting indemnification for moral damages. The Judiciary of the affected cities was not prepared or equipped to deal with these claims. A magistrate that was well adroit of the intricacies involved in the new Brazilian Civil Procedure Code, proposed a strategic solution: an aggregate claim, i.e., a method for jointly adjudicating aggregate claims in the State Court of Justice. The procedure was deemed acceptable and all claims of individual parties with the same common complaints were suspended to wait for the Court ruling that would determine the outcome of the aggregate litigation case. Questions arise: What is the procedure for the new technique? How to ensure the plaintiffs' rights to challenge the Judiciary and the counterparts when their lawsuit has been suspended? How to dispense the Court ruling to all the individual pending cases?

The underlying idea brought herein is to debate the New Brazilian Civil Procedural Code. Particularly, regarding the adjudication technique for aggregate litigation cases that, little by little, became widespread in Brazil. This technique has its roots in a worldwide movement that pursues the goal of turning civil Justice more rational. It also serves as an alternative to the American model of opt-out class actions, especially the claims for damages.

It must be mentioned that legal traditions are in permanent dialogue. The legal concepts and remedies, contrarily to what was thought of until recently, are not totally separated by geographical, cultural and continental dimensions. From the need of tackling common problems arises an interconnectivity between these concepts. And what was said about concepts is also applicable to people. Therefore, a comprehensive view of problems in common can enable a more cosmopolitan approach to finding solutions, and this cosmopolitan approach should be construed 
as the most rational, while, at the same time, contrastively, it safeguards the interests of the parties involved in a mutual dialogue of commitments.

Legal traditions, as scholars have been defending, are neither mutually exclusive, nor static. The life of legal traditions is inclusive and dynamic. As of $1980 \mathrm{H}$. Patrick Gleen (2014) outlined the foundations for a deeper understanding of legal traditions from a historical and comparative perspective. H. P. Gleen (2014), insisted that the law was the result of a rich dialogue between local rights and legal forms throughout history. Legal traditions are, consequently, dialogic, dynamic and interactive. The purpose of comparative studies is to seek an understanding between the Law and legislation to the same degree we seek appeasement between people.

The changes brought by the new Brazilian Civil Procedural Code of 2015 follow a global trend for rationalization of justice and the optimization of resources - human and financial required to deliver justice as a public service. A wide variety of techniques are available to the legislator to reach the goals of providing the means to achieve a faster, more economical, safer and more efficient judicial system.

Brazil has selected a true array of techniques that were designed to serve the purpose. The Judiciary of multiple doors, the precedents, aggregate litigation, and class actions are examples of these techniques. Because of this plethora of solutions, it becomes unavoidable that they might overlap, with the emerging of convergence zones and friction zones.

An example of this overlap is the relationship between aggregate litigations - which we will approach, here, as a kind of opt-in class action - and opt-out class actions as well as the binding precedents as expressly foreseen for by the CPC/2015.

Thus, first we will approach aggregate litigation, followed by the relations between aggregate litigation and class actions, and, finally, between aggregate litigation and formally binding normative precedents.

Comparing the French and the Brazilian law can greatly benefit the legal culture about the new Code of Civil Procedure because the CPC/2015 is part of a new era in terms of codification models, and its example is the French Civil Procedural Code of 1975. Codes of the "Recodification Age" (IRTI, 1999) are constitutionalized, open, flexible, and permeate a continuous adaptation of its contents to the purposes and rights it is entrusted to protect. That is the case with the French and the Brazilian codes, which makes them "codes of doctrine", paraphrasing a most enlightening expression used by Loïc Cadiet $(2011)^{2}$. This means that the new legislation in reference was not created by the legislator sponte propria, but, instead, emerged from a progressive consolidation process based upon the civil procedural doctrine and its source values that are the building blocks in procedural law, such as the doctrines of cooperation and the right to challenge, deeply embedded into the paradigm of the Democratic Constitutional State as the medial point, in medium virtus, between the liberal and the social models of procedure.

\section{AGgREgATE LITIGATION: THE AGGREgATE CLAIMS (IRDR) AND AGGREGATE APPEALS (REER)}

The technique of aggregate litigation is a method of combining cases of identical nature, in terms of procedural or subject matter, to have the contended subjects adjudicated together. There are two types of aggregate litigation as foreseen by the new legislation. Rulings emanated from aggregate claims (IRDR) and from aggregate appeals of either infra constitutional or constitutional

\footnotetext{
2 This new civil procedure is prepared to face the increase in managerial powers of the judge, while delivering more autonomy to the parties through the auto-regulation of the procedural volition. In Brazil, as examples, respectively, the broad powers of the judge to enforce judicial decisions (article 139, IV, CPC) and the atypical procedural conventions (article 190, CPC). These changes allow for tailor-made lawsuits, envisioned to solve nowadays problems in a dialogic, dynamic and interactive manner, focused on real cases and in the protection of rights, delivering to the people under that jurisdiction, to the consumers of the judicial services, what is due to them.
} 
matter (REER) are considered aggregate litigation ${ }^{3}$. Reading the legal text, we can conclude that factual controversies are excluded (art. 928), the aggregate litigation in Brazil deals only with law issues, but this is not an easy distinction (ZANETI JR., 2015; DIDIER JR.; CUNHA, 2017b; DIDIER JR., s.d.; DANTAS, 2017). ${ }^{4}$ By definition, this is a managerial and adjudicating technique applied to lawsuits, which was conceived, in Brazil, as per what is explained in the rationale of the $\mathrm{CPC} / 2015$ Bill submitted to Congress, on the footprints of the experiences of the KapMuG (BAKOWITZ, 2014) ${ }^{5}$, also known as Musterverfharen, from German law ${ }^{6}$. As we shall see, the concept is only inspired by its Germanic precursors' ideology, but is not the same procedure.

We can say that the inspiration for the Brazilian law was the Musterverfharen, but also other aggregation techniques like the American Multidistrict Litigation - MDL or the English Group Litigation Order - GLO are concerned with the same common goals of efficiency, consistency and equality of decisions on serial claims.

\subsection{Historical precursors, inspiration and ideology}

In Germany, the well-known Musterverfharen experimental technique emerged to the solution of stock market cases, testing a pilot legislation that had an expiration date scheduled for 2020 (Section 28, KapMuG Act). Contrastively, in Brazil, it is implemented as a permanent technique, with no prior experimentation or validation of the procedural model.

A closer look at the procedure of the German model reveals that the similarities are not as representative as initially purported. However, it is undeniable that a communion of intentions is present. Similar techniques for aggregating individual claims can be found in English law, such as the GLO - Group Litigation Orders ${ }^{7}$, as well as in the United States law, such as the MDL Multidistrict Litigation ${ }^{8}$. All the practices mentioned above deal with aggregate litigation techniques.

\footnotetext{
3 About the subject of aggregate litigation in Brazil it is possible to identify a dogmatic model, for a better understanding, reading Articles 928, 976 through 987 (IRDR) and 1036 through 1041 (REER), CPC.

${ }^{4}$ Instead the KapMuG/Musterverfharen (Section 2, (3), Capital Markets Model Case Act), the MDL ( (a) 28 U.S. Code $\S 1407)$ and the GLO (19.10, CPR) are all concerned with issues of fact and law.

${ }^{5}$ An interesting aspect highlighted by the author is the tendency of the legislator to direct this model, originated in 2005 and reformed in 2012, to encourage agreements between the parties (ibid., p.164, Sections 17 to 19 of the KapMuG Act). An English version of the Act of 2012, already amended, available on the website: https://www.gesetze-im-internet.de/englisch_kapmug/index.html, accessed on 17.01.2017.

${ }^{6}$ This procedure was mentioned in the rationale (explanatory note) of the CPC's original Bill sent to Congress: "With the same objectives [efficiency of the adjudicating system of aggregate claims], it was created, by inspiration of the German law [In German law, the concept is called Musterverfharen and it generates a ruling that serves as a model (= Muster) to the solution of an expressive number of cases in which the parties are in identical situation, not necessarily involving the same plaintiff and the same defendant], the aforementioned aggregate claim (IRDR), which consists in the identification of cases that contend about the same legal claim, which are still held in suspension at the first level of adjudication, in order to receive a joint ruling" (Commission of Jurists Responsible for the Drafting of the Bill to be presented for legislative approval as the New Code of Civil Procedure: Preliminary Draft: Brasília: Federal Senate / Presidency, 2010). Cf., for other references, the groundbreaking work of Antonio do Passo Cabral and the author's subsequent studies about IRDR. CABRAL, 2007; CABRAL, 2014; CABRAL, 2016a; CABRAL, 2016 b, p. $263 / 281$.

${ }^{7}$ News of the English procedural law after the codification of the reforms of Lord Woolf, cf. rules 19.11 and following of the CPR - Civil Procedure Rules, see also ANDREWS, 2007; ANDREWS, 2009a, 2009b.

${ }^{8}$ In the definition: "multidistrict litigation. (1966). Civil procedure. Federal-court litigation in which civil actions pending in different districts and involving common fact questions are transferred to a single district for coordinated pretrial proceedings, after which the actions are returned to their original districts for trial. Multidistrict litigation is governed by the Judicial Panel on Multidistrict Litigation, which is composed of seven circuit and district judges appointed by the Chief Justice of the United States. 28 USCA § 1407”. O acronym is MDL - Multidistrict Litigation, cf. GARNER, 2013. The rule is foreseen in the United States Code Annotated, 28 USCA § 1407. In Brazilian Law there is a legislation that allows merging lawsuits for the sake of judicial cooperation, which could be implemented to
}

Revista de Direito Brasileira | Florianópolis, SC | v. 24 | n. 9 | p.428-443 | Set./Dez. 2019 
The purpose of all these aggregation procedures is to promote and safeguard the efficiency of justice mechanisms through the rational deployment of public resources, swiftness in the delivery of judicial adjudication and the facilitation of high quality conflict resolution through fair trials. In summary: isonomy, legal certainty and procedural speed.

In addition, in many jurisdictions the purpose of aggregate litigation is to serve as substitutes for the class actions as purported by the North American model, particularly considering the reluctance with which it is seen by the market and some nations, as it happens with the European Union $^{9}$, in reference to the adoption of the opt-out class actions model, due to the dangers that it could potentially pose if it altered the legal tradition of countries who abide by the ruled of the civil law, resulting, as a consequence, in legal and economic uncertainty ${ }^{10}$. In the polarization between the "Frankenstein Monster", the "Big Bad Wolf" and the "White Knight", to this day, in Europe prevailed the negative publicity of some notorious opt-out class actions in which abuses occurred in the protection of collective rights ${ }^{11}$. Proponents of opt-out class-action models argue that they refrain the abuse of illicit market practices through the use of private enforcement; The detractors consider these actions as the representation of a kind of legalized blackmail ${ }^{12}$.

After a quick glance it becomes apparent that this is a debate marked by adjectival, ideological positions that, often, walk away from the legal interest that is supposedly protecting.

Brazil, which is already recognized for adopting, at the same time, the American constitutional control model of diffuse proportions in addition to the concentrated constitutionality control of the European model, once more, innovates and comes ahead by adopting a mixed model of collective protection of groups' interests allowing, at the same time, the opt-in and the opt-out class action.

\subsection{Collective litigation: the formation of the opt-out and the opt-in groups}

We believe that this kind of protection of rights represented by the technique of aggregate litigation can, therefore, be seen from the perspective of a collective redress, no matter what its configuration $^{13}$. It should be understood as a collective redress because groups are created from the

achieve the same goals (Article 69, CPC). There is a recent work proposing the centralization of lawsuits as necessary step to the IRDR: CAMARGO, 2017, p. 419.

${ }^{9}$ It is not by chance that the class actions were openly rejected as 'not desirable' in 2007 in the Committee for the Protection of Consumer Rights of the European Union: "Such an attitude is epitomized by a passage in the speech given by Ms. Meglena Kuneva, the European Union Commissioner for Consumer Protection, at a conference on collective redress held in Lisbon towards the end of 2007. While stressing "how important it is to ensure that consumers can confidently enforce their rights across the European Union", and acknowledging that "collective redress, both judicial and non-judicial, could be an effective means to strengthen the redress framework that we have already set up for European consumers", the Commissioner took a stand against class actions, and said: "To those who have come all the way to Lisbon to hear the words 'class actions', let me be clear from the start: there will not be any. Not in Europe, not under my watch", cf. SILVESTRE, 2010, p. 99 ss.

${ }^{10}$ To a broader reference about the problem cf. several articles published in HARSÁGI; VAN RHEE, 2014, that, deepen the subject further, demonstrating the insufficiency of the model of the aggregate cases to deal with problems related to collective redress. In France see also "La différence réalisée entre l'agregate litigation et les class actions évoque, en France, la nuance entre l'action collective qui est devenue l'action en reconnaissance des droits et l'action de groupe.' STRICKLER, Yves. Le Traitement des Procédures en Série.

${ }^{11}$ For the classical article quoted by the doctrine multiple times cf. MILLER, 1979, p. 664-694. Miller defends class actions as a form of litigation justified by the defense of civil rights, environment, consumer rights and antitrust law, stating that after the reforms of 1966, class actions would not be a problem, but a solution. There are obvious problems in class actions and there were judicial errors in the past. However, we see its existence as needed nowadays to safeguard the fundamental right of the appropriate delivery of the adjudication within the judicial service that is guaranteed by most modern constitutions, which should be, obligatorily, broadened to include situations such as aggregate claims.

${ }^{12}$ A brief survey by Stefaan Voet (s.d.) points in this direction.

${ }^{13}$ Accordingly, cf. DIDIER JR.; ZANETI JR., 2017, 2016.

Revista de Direito Brasileira | Florianópolis, SC | v. 24 | n. 9 | p.428-443 | Set./Dez. 2019 
moment the various disputes, or the issues that arise from these various disputes, are brought together. It is the adjudication of aggregate litigation, aggregated claims, isomorphic disputes, in a few words, opt-in class actions; in which, an active behavior is required of the parties for the group to be formed, for example, by filing individual lawsuits so that they can be included and linked to the outcome of the collective process.

This theory is ratified by the American Law Institute (2014) because, when it regulates the types of collective cases, it defines both types - class actions and aggregate litigation - in the same article and as species of the same category $(\S 10.2)^{14}$, as well as by the GLO - Group Litigation Order from England, that also recognizes the need for joint treatment (19B 2.3) ${ }^{15}$. According to the English rule, it is the analysis of the circumstances of a particular case what will allow us to determine the most appropriate mechanisms to handling the litigation.

This option has some advantages, as we will see later, when the situations of aggregation of cases overlap the situations of the class actions. The most rational solution is to contemplate when it is considered a typical case for class actions, when it is considered a typical case for aggregate litigations and how to proceed when the same legal situation at hand fits both procedures concomitantly.

\subsection{Description of the Aggregate Claims Procedure and the Rules that are common to the Aggregate Appeals}

For an aggregate litigation claim procedure to start, the action of one of the persons below is required: a magistrate, the parties, a public prosecutor or a public defender (Article 977).

The aggregate claim will be adjudicated by a body of judges designated according to the internal regulations of the Judiciary court where the claim was filed, chosen among those responsible for the standardization of jurisprudence (Article 978). The analysis of admissibility of the claim will be made by the same collegiate body and all judges must manifest their opinion about the admissibility (Article 981).

For an aggregate litigation procedure to be started, there are admissibility prerequisites foreseen by law. These prerequisites determine that the claim will be inadmissible when it is found to be a proven repetition of claims that contain previously analyzed controversy about a matter that dwells solely about questions of Law (as opposed to factual matters), incurring, also, in a risk of offending isonomy and legal certainty (Article 976). In addition to these two requisites, a claim pending of judgement in that court is required. That happens because the collegiate body, the panel, in charge of deciding and determining a legal opinion to settle any legal matter being discussed shall use the same decision and legal opinion for all identical cases after the first leading case has been decided. Henceforth, future identical issues or lawsuits will necessarily be claimed by the same body who holds the expertise to solve that same matter contended by a different party (Article 978, sole paragraph).

The stay of pending aggregate litigation cases in court for future decision is defensible from a systemic point of view. In the situation of the aggregate appeal there is a need for the case to be pending in court (Article 1036). It is also needed in face of the Brazilian tradition in adjudicating cases, without which, the procedure of trying cases in aggregate appeals would become an objective process, a process without parties.

\footnotetext{
${ }^{14}$ The difficulties of translating the expression aggregate litigation as reported by Francisco Verbic (2007) denote how correct it is to study the subject under a common branch or axle of the collective processes in the civil law and hybrid countries (idem, p. XVIII).

${ }^{15} \mathrm{Cf}$. 19B 2.3 "In considering whether to apply for a GLO, the applicant should ponder whether any other order would be more appropriate. In particular, he should consider whether, in the circumstances of the case, it would be more appropriate for - (1) the claims to be consolidated; or (2) the rules in Section II of Part 19 (representative parties) to be used."
}

Revista de Direito Brasileira | Florianópolis, SC | v. 24 | n. 9 | p.428-443 | Set./Dez. 2019 
About the subject, we must admit that in Brazil there is currently a great controversy regarding the legal nature of the aggregate claims (IRDR) involving two main legal opinions that compete in Court today. Scholars have been discussing about whether, or not, to adopt the German model of the "model case", Musterverfharen, or the Austrian model, pilot-verfharen, the "pilot case" (MENDES, 2017).

The first model offers an aggregate claim that is different from the Brazilian system, being closer to an adjudicating technique without a subjective claim. Scholars see this category of aggregate claims as a technique to objectively judge homogeneous or isomorphic situations (BASTOS, 2010) ${ }^{16}$.

The second model, as defended here, is a technique to judge matters of material or procedural law, which must be judged by a court concomitantly with a claim, a lawsuit, that has been admitted for judgement by such court.

As we defend it to be a collective process to safeguard the rights of a group - that was created with the IRDR or the REER - in which the collective legal situation is the discussion of a legal thesis - opinion - of material or procedural law, necessarily linked to a concrete legal conflict being discussed in court, this condition is imperative for the admissibility of the aggregate litigation procedure.

This is an important point if we are to maintain a parallelism between the aggregate claims judged by a panel in an intermediate court and the aggregate appeals of constitutional and of infra constitutional matter, because these appeals require the existence of a case being judged by the court and for the eventual consolidation of a binding precedent resulting from the decisions in aggregate litigations. The more the decision adheres to the legal subject discussed in the leading case, the better the decision will suit the needs of fair justice. It is the universalization of circumstantial relevant facts (material facts) that are discussed to reach a legal solution that will allow the formation of adequate legal basis (ratio decidendi) suitable to be applied to future cases (Article 489, §1, V and VI) as binding precedents.

All these conditions related to the admissibility requirements are sufficient to indicate that, in these procedures, we are delineating, at this moment, a fair process as the situations are being analyzed by the courts. Accordingly, Luiz Guilherme Marinoni (2016, p. 2.174) states that there are: "three values that should enlighten the understanding of the legal concept: procedural economy, coherence and the challenging doctrines. To interpret it as a mere instrument for a swift collective conflict resolution is to reduce it to only one of its functions." (MARINONI, 2016).

Legislation, however, if analyzed through a systemic perspective, is sufficient to provide many safeguards, which need to be taken seriously. There is a strong incentive to broaden the debate, with the possibility of admitting amicus curiae and public hearings, as well as widespread dissemination of the claim by the global network of computers through the use of national and regional registries on the websites of the judiciary (Articles 983 and 979).

This requisite to broaden the debate is reinforced by the need for the decision to take into consideration all the pleas that were raised in connection to that legal decision, whether in favor or contrary to it (Article 984, § 2).

Taking into consideration the broadening of the debate and the specific reasoning required in the rulings, scholars defends the control of the affectation, meaning the choice of the cases that will be judged, of the procedure and the formation of the legal thesis through the concept of "argumentative representativeness"17 (Article 1036, §6). This concept, which is common to

\footnotetext{
${ }^{16}$ Accordingly to the author, aggregate litigation are based on homogeneous legal situations that fit a typical profile and that are not reducible to the homogeneous individual rights.

${ }^{17}$ Luiz Guilherme Marinoni (2016a, p. 2175) defends that, to solve the problem, the CPC/2015 foresees an idea of "argumentative representation", when it authorizes the participation of the interested parties in the controversy (arts. 983 e 1.038) and establishes, in the case of the aggregate claims (IRDR), the analysis of all details of the contended Revista de Direito Brasileira | Florianópolis, SC | v. 24 | n. 9 | p.428-443 | Set./Dez. 2019
} 
aggregate litigation, bears a strong resemblance with what is already known about collective processes, but it transcends it, because it also allows a control over the establishment of the precedents.

The choice of which cases will be affected (choose as pilot cases) to be adjudicated is very important for the preservation of this requirement of argumentative representativeness. The choice of the adequacy of representation of the parties idem. More will be said about the subject when we discuss about the concomitance accumulation between aggregate litigation and class actions.

Further about the procedure. It is important to emphasize that after the affectation is decided, there will be an analysis of admissibility of the aggregate claim and of the aggregate appeal, which allows the suspension or stay of all the ongoing lawsuits that are being processed, in first analysis, with the same claim within the territorial jurisdiction of the court to which the claim is affected (Article 982, I) and, in a second moment, for both, throughout the national territory, if this is the understanding of the courts in charge of adjudicating appeals of, either, infra constitutional or constitutional matter. These cases that had been suspended will, subsequently, be judged according to the legal thesis defined by the model leading case (Articles 982, §3 and 1036, $\S 1$ ). Here the legislation creates some important guarantees to the members of the group (suspended lawsuits), which are resultant from the joint reading of the two species of aggregate litigation foreseen in the CPC.

Initially, the parties should be summoned of the 'stay' decision that suspends their lawsuit (Article 1037, §8). Once their process has been served, the parties may bring evidence of distinction between the matter to be decided in the leading model case and their own legal conflict, requesting to the judge in reference, if applicable, that their case should proceed (Article 1037, $\S$ 9-13). There is a possibility of requesting urgent provisions, and such request can be directed, depending on the case, to the judge of the case suspended or to the judging panel that was commissioned to process the future application of the thesis to be decided (Article 982, 2 and $1037, \S 10)$.

In any case, the party has the right to withdraw from the aggregate claim or appeal (Article $1040, \S 1$ ). The maximum timespan for the matter to be adjudicated is one (1) year, and there is a right of way for the adjudication of aggregate claims or appeals over other individual cases waiting to be judged. The extension of the deadline is only allowed with a reasoned decision (Articles 980 and 1037, §4). Practical experience with aggregate appeals, existing before this new Civil Procedural Code, has shown that this deadline is rarely met. Considering the importance of these procedures and the stay of thousands of individual lawsuits awaiting adjudication, it is our opinion that reasonable compliance to the deadline is fundamentally important for the delivery of a fair judicial service and for the success and longevity of these aggregate techniques.

Once the matter contented in the leading case is decided, the judges responsible for the aggregate cases of identical controversy will adjudicate by applying the resulting thesis (Articles $985, \mathrm{I}, 1039$ and 1040). It is worth mentioning that the suspended lawsuits may have been filed at different points in time in the past - from recently filed lawsuits to cases about to be judged by Superior or Supreme courts - this particularity will result in some procedural specificities. In the case of aggregate appeals, the decision may deem a certain case inadmissible when the arguments of the contested decision are in aligned with the resulting thesis (Article 1040 (1)).

A final question must be answered regarding the stabilization of the legal thesis. The matter being judged is not rendered final through the adjudication of aggregate litigation, because its function as stabilization technique, instead, is to settle a thesis. The application of this thesis will generate, in each case, the adjudication of the case that would, then, be subject to res judicata.

It should be noted, however, that the legal system continues to differentiate class actions and individual lawsuits res judicata. 
There are in, these procedures of aggregate litigation, two dissections, a cognitive and a decisional split. The committee or panel that adjudicates the aggregate claim or appeal will not be the same to apply the final chosen legal thesis, with the exception of the pilot case. As for the pilot case, it may be used to rule over a lawsuit that may discuss more legal issues than the leading pilot case decided upon, situation in which, first, it will be adjudicated about the common subjects and, then, the other chapters (Article 1037, § 7). It will be judged in its entirety by the committee or panel that is responsible for that aggregate claim or appeal. This makes the peculiarities that differentiate class actions and individual actions be highlighted, as we will discuss in the appropriate topic.

There is no doubt about the rationalization that a procedure of the sort of aggregate litigation infuses to the trial, with the application of the legal thesis to all cases filed within the jurisdiction of the adjudicating body and; in the case of aggregate appeals of infra constitutional or constitutional matter, throughout the national territory. This represents enormous benefit for the purposes of isonomy, legal certainty and procedural swiftness.

However, without a fair process that allows this technique to be used with the necessary care, some important procedural and substantial guarantees may be adversely affected in the delivery of justice. A topic of particular interest is to construe the relations between aggregate litigation and the previously existing - and effective - class actions opt out system in Brazil. Another point of interest, perhaps of even more serious repercussions because it is more recent, is the discussion about the interconnectedness between aggregate litigation and the judicial binding precedents.

\section{AGGREGATE LITIGATION AND CLASS ACTIONS}

Aggregate litigation in Brazil affect both, individual and class actions cases that are being judged. ${ }^{18}$ Once the aggregate appeal has been admitted all previous individual claims or class actions claims about the subject will have its procedure suspended. The resulting legal thesis to be applied to the aggregate claims will be employed to individual lawsuits and class actions (articles $982, \mathrm{I}, 985$, I and 1036, § 1). Suspension and application of the thesis directly touch the expectations of the parties interested in the case(s) and those with legitimate interest in seeing the class actions' decision.

The goals of the class actions and aggregate litigations are, in part, convergent, but not identical. In the aggregate litigation, there is technique concerned with the management of aggregate claims. Thus, the main values at stake are isonomy, legal certainty and speed, which can also be translated to procedural efficiency.

Full protection of rights, especially of the new rights, such as consumer and environmental law, is not the main concern, nor is it even a fundamental justification for aggregate litigation. Thus, the members of the group are fragmented to guarantee protection only to those who effectively choose to file lawsuits. It is a mode of collective processes, in which the group is formed from the admissibility of the aggregate claim, from those who chose to file the action.

\footnotetext{
${ }^{18}$ About the scholars' opinions on the difficult task of conceptualizing diffuse and the collective rights: GIUSSANI, 2008; DONZELI, 2008, 2011; COLAÇO ANTUNES, 1989; SOUSA, 2003; SALGADO, 2011. The guidelines may vary, but the common problem persists, to recognize a legal interest protected by the norm to allow judicial protection of these new emergent situations of the mass society. This problem does not arise in the common law because it is not concerned with a previous acknowledgement of a subjective right as a requirement for its legal protection. Some authors have tried to give a more pragmatic solution to the problem, using the North American model, avoiding conceptual notions, cf. VERBIC, 2007; GIDI, 2008 (reviewing the position adopted in Id. Coisa Julgada $e$ Litispendência nas Ações Coletivas, São Paulo: Saraiva, 1995). What is certain is that hybrid systems, common law and civil law at the same time systems (ZANETI JR., 2014), like the Brazilian case, depend on the two approaches, the dogmatic-conceptual and the pragmatic-realist, to become both universal (reaching all) and effective (solving the concrete problems that are linked to collective redress).
} 
It is precisely in this sense, for this purpose, that we can say that it is a class action in which the formation is opt-in (in which the parties may choose if they want to be part of the protected group). Undeniably, if admitted to the claim, the parties may withdraw and not be affected by the outcome, but the group has already been formed, the group is formed within the opt-in mode even before the claim - with the mere filing of the action that contains the question of repetitive matter.

Only those who choose to join the actions will be affected. They will affected either, positively and negatively, if the claim rejected by the judge. It is not a matter of res judicata, but of the application of the legal thesis that has been established for each individual or collective proceeding, which had been suspended for judgment of the aggregate claim. The res judicata, if applicable, will come later, when the judge of the case that had been suspended, resumes the proceedings and adjudicates about that lawsuit.

In this context, it is very important to file class actions and the rule of adjudicating class actions as pilot-cases affected jointly or preferentially to the individual cases, when the multiple claims also deal with the new rights that require the full protection to all members of the group. This occurs because, once filed, the class action will guarantee, if successful, full protection for all members of the group regardless of having filed individual lawsuits. The group, in the collective procedure of class actions, is formed opt-out, that is, all subject who have the same claim are already included in the group, without the need of any individual manifestation. Everyone in the group will benefit.

It should be noted that we are not talking, here, about opt-in and opt-out class actions in relation to the final connection of the group, which may or may not occur according to the regulations of each type of legal system. In Brazil, for example, the holders of the individual rights members who are members of this group will only be affected in their individual rights when it is to their benefit and only if the judgement was given with sufficiency of evidence (subjective extension secundum eventum litis and res judicata secundum eventum probationem $)^{19}$. The element of differentiation that we are emphasizing is the way the group is formed and the concern to assure full protection for the whole group or a fragmented tutelage, only for part of the group.

The need for differentiation between techniques stems from the legal requirement to guarantee an adequate fair process to each of the collective processes types, in addition to the fact that, accumulation between aggregate litigation and class actions will not always be present.

There may be class actions that do not generate aggregate claims because of the inexistence of repetition of individual lawsuit claims. Additionally, there may be well-founded aggregate claims about procedural questions ${ }^{20}$. More than that, the correct view of this phenomenon allows to control the admissibility of a claim by giving priority to class action and the admissibility of a class action with giving priority to the claim, preventing the continuation of a potential inadequate procedural technique for the protection of rights ${ }^{21}$.

${ }^{19}$ For details about res judicata secundum eventum litis and secundum eventum probationem in Brazil cf. DIDIER JR.; ZANETI JR., 2017, p. 423-436. These techniques have been mentioned as an alternative for the situation in France by FERRAND, 2014; HARSÁGI; VAN RHEE, 2014, p. 145.

${ }^{20}$ As well noted by TEMER, 2016, p. 63.

${ }^{21}$ As stated, "the use of one technique or the other will depend, on one hand of the strategic definitions of the litigants: collective legitimacy, group members (occasional litigants), and habitual litigants. The quest for (or the caution against) a res judicata or a mandatory precedent are the variables around which discussions about costs (financial, political, social, etc.) of the litigation will arise. Options such as relinquishing an ongoing case (Articles 976, §1, 998, sole paragraph and 1040, $\$ 1, \mathrm{CPC}$ ), the intervention as amicus curiae or interested party (Article 983, CPC), filing the claim, the choice of the leading case from which the claim will start, of the choice of a class action are tools available to the parties while defining their procedural strategies [...] the choice of the technique to be used must observe the principle of adequacy. It is also dependent upon the group's procedural strategy." (DIDIER JR.; ZANETI JR., 2017, p. 99). 
From this description we need to build a fair process, the due process of law of the Brazilian collective process, which allows the compatibility of the two types of collective process, opt-out and opt-in, class actions and aggregate litigation, and which ensures adequate protection to the legal matters being discussed in court ${ }^{22}$.

As we mentioned before, one of the key aspects will be the choice of the pilot-cases. In case there is an ongoing class action, the pilot cases should include the affectation of the class action for joint judgment with the legal thesis. In case this lawsuit has not arrived at the court yet, the aggregate claim or the aggregate appeal must be rejected to avoid putting at risk the "argumentative representativeness" in the formation of the thesis. Only the class actions opt out deal with the correct extension of arguments and the adequacy of representation needed to adjudicate new rights.

We understand this concern is justified as means to avoid, as it has already happened in a case heard by the Superior Court of Justice, which discussed the base telephonic land-line fee, a problem that affected thousands of telephone users in Brazil, with thousands of individual lawsuits and some class actions filed, in which the court accepted the affectation of an infra constitutional Superior Court (STJ) aggregate appeal of an individual consumer that was three times vulnerable, and that, through the "back door" transformed the individual action of a weak and vulnerable litigant, unable to pay for lawyers to act together before the Superior courts, turned into a reverse class action ${ }^{23}$.

Therefore, when dealing with new rights such as consumer rights and environmental rights and other material claims that require full protection, such as social rights, the judgment of aggregate litigation will necessarily depend on the affectation of a class action as a pilot-case.

Regarding the res judicata in collective proceedings, Brazilian law, despite having followed the American model of opt-out class actions, does not bind the members of the group in their individual rights, the absent members are not affected. This creates a distinction between class actions and individual lawsuits that were suspended by the aggregate litigation judgment technique.

In the case of individual lawsuits, the holders of individual rights will be affected pro et contra, generating res judicata in each case that was filed individually, after the general legal thesis that was established is applied to it. There will be res judicata, both, to benefit and to damage the holder of the individual right, when judging the previously suspended case with the application of the legal thesis that was settled with the aggregate appeal. The regime of the individual res judicata applies normally after the application of the thesis.

In the case of class actions, something different happens, the holders of individual rights will only be affected positively, that is, the subjective extension of the res judicata will be secundum eventum litis only to benefit the holders of the individual rights in case of a successful result. It is true that they will be subject to the effects of the precedent that will, eventually, be created by the judgment of the aggregate litigation case, but there will be no unfavorable res judicata to the holders of the individual rights. However, the res judicata in these cases will prevent the resubmission of a class action about the same matter that has been decided, regardless of the party having been - or not - a plaintiff, but the rule does not apply to individual actions.

\footnotetext{
22 Accordingly, Stefaan Voet (s.d., p. 56): "The bottom line is to connect the different dots. To put it simply, the approach should be 'and ... and' and not 'or ... or'. It is not choosing between white or brown bread, it is looking at how it is baked. The ultimate goal should be an integrated and holistic framework, or, as was mentioned above, a 'multilayered framework of regulation, lawmaking and law application" [...] "The focus should be on exploring and optimizing all options for mass harm situations. Even more important, is to connect these options so they can form an integrated (dispute resolution) framework. Only a broad and integrated instrumentarium, as a "dispute resolution continuum', which can avoid empty enforcement gaps, can tackle mass harm situations effectively and efficiently".

${ }^{23}$ The precedent has generated an understanding that was published through the Enunciado n 356 for the Sumulae of the STJ.
} 


\section{AGGREGATE LITIGATION AND THE PRECEDENTS}

The CPC foresees that once a claim or an aggregate litigation has been adjudicated, the resulting legal thesis will be applied to all individual or collective proceedings that are ongoing or suspended due to judicial determination, and it also determines that such thesis will apply to future claims and lawsuits and forwarded to the applicable government agencies that are in charge of enforcement, so that they can act accordingly, whenever the aggregate litigation has connection to services rendered, allowed or authorized by a Public Authority. Aggregate litigation rulings carry a double discourse: one, of the case and, the other, of the precedent. ${ }^{24}$

The CPC also foresees that the legal theory established in the aggregate claim should be reviewed by the same court, ex officio or at the request of the Public Prosecutor's Office or the Public Defender's Office. In addition, the CPC also lists aggregate litigation among the formally binding precedents, according to the text of the CPC, the judges and courts are obliged to follow the legal thesis resulting from aggregate litigation ${ }^{25}$.

The requirements to be able to discuss binding precedents are formal and material, for this reason, not every decision of aggregate litigation will be a precedent. It may only be the application of a law, in which case it does a precedent is not formed because the law is, in itself, binding, not needing confirmation of the Judiciary to make it binding. The decision of the aggregate litigation can also be the application of a previous leading case, which is already a precedent in itself, being, at most, a reinforcement in the chain of this precedent, from which it removes its binding effect. But what is most remarkable is that the decision of aggregate litigation must meet some requirements in regards to the determinant grounds (ratio decidendi) and respect the exceptions to the application of the precedents consisting in the possibility of distinguishing and overruling.

Precedents are general and concrete rules, that can only be observed if it is possible to identify the relation between the factual circumstances and the legal solution to the precedent case in relation to the factual circumstances and the legal solution of the current case at hand. This operation is guaranteed normatively by the text of the provisions of our Code of Civil Procedure, the application of legal theory should not be mechanical and abstract.

This is very important, especially for future cases, since it is for these cases that the precedent is formed. For future cases, it should be safeguarded the rights to contradict and adequate justification according to the model of precedents adopted by Brazilian legislation. First, there are no precedents without stare decisis, therefore, the court itself is bound to the established legal thesis, maintaining stability, coherence and integrity of its precedents.

All these concerns are related to the fair process, the impacts of the precedents will occur throughout the lifespan of the procedure, from the filing of the lawsuit to the implementation of the ruling and the satisfaction of the contended rights. In the Brazilian CPC precedents allow the dismissal in liminis of the lawsuit, the protection of the evidence, the urgency protection, the monocratic adjudication by the rapporteur in collegiate decisions, the courts, the inadmissibility of constitutional appeals, rescission of judgment lawsuits, and a number of other important consequences. Precedents are norms, primary sources of Brazilian law, therefore, its formation, application and overruling are normative activities that must be controlled by the law for the purpose of reducing judicial discretionary powers and guaranteeing the independence of judges and courts.

\footnotetext{
${ }^{24}$ About the subject, cf. MITIDIERO, 2012, p. 91; DIDIER JR.; BRAGA; OLIVEIRA, 2015, p. 281/282; ZANETI JR, 2017, p. 388.

${ }^{25}$ About the precedents in Brazil, it is possible to identify a dogmatic nucleus for its understanding in arts. $489, \S 1^{\circ}$, V e VI, 926 e 927, CPC
} 


\section{CONCLUSION}

Today Brazil faces a great opportunity and a great challenge, our legislated procedural law acts as an interface between the civil law and the common law, a hybrid model. We have over 110 (one hundred and ten) million individual ongoing cases and class actions, hence, we need to guarantee a system of justice that can possess all the assets that can enable us to have, at the same time, protection of rights, isonomy, agility and certainty. Our economy needs it almost as much as our people, the consumers of justice.

Aggregate litigation, class actions and binding precedents contribute to the achievement of this goal and are interconnected at its core. They are, therefore, instruments to achieve the desired outcomes, in a musical analogy, they are the piano from which we should emanate our best songs, the best sonorities, and more harmonic resonances. We hope the scholars and our legal doctrine may, somehow, contribute to the convergence of all tenets involved and that the pressure for immediate results does not jeopardize other pursued aims.

The case of the environmental disaster of Mariana/MG shows how many legal situations can emerge and can be combined into a single generating fact, a multiplicity of individual and collective claims, at the same time aggregate litigation, class actions opt out and the opportunity to establish precedents. Procedural rules must serve the protection of rights in a timely, effective and appropriate fashion. Only an adequate protection of the rights can serve the interests of a case and, at the same time, universalize the decision for future cases, guaranteeing rationality, isonomy and certainty.

\section{REFERENCES}

American Law Institute (ALI). Principios del Derecho de los Procesos Colectivos (Principles of the Law of Aggregate Litigation). Trad. Francisco Verbic; Jorge A. Sánchez Cordero (coord.). México: Instituto de Investigaciones Juridicas/UNAM, 2014.

ANDREWS, Neil. Complex civil litigation in England. Revista de Processo, São Paulo: Revista dos Tribunais, vol. 153, p. 87, Nov. 2007.

ANDREWS, Neil. Controversie collettive, transazione e conciliazione in Inghilterra. Revista de Processo, São Paulo: Revista dos Tribunais, vol. 169, p. 62, mar/ 2009a.

ANDREWS, Neil. Multi-party litigation in England: current arrangements and proposals for change. Revista de Processo, São Paulo: Revista dos Tribunais, vol. 167, p. 271, jan/2009b.

BAKOWITZ, M. The German Experience with Group Actions - The Verbandsklag and the Capital Markets Model Case Act (KapMuG). In: HARSÁGI, V .; VAN RHEE, C. H. Multi-party Redress Mechanisms in Europe: Squeaking Mice? Cambridge: Intersentia, 2014, p. 153/170.

BASTOS, Antônio Adonias Aguiar. Situações Jurídicas Homogêneas: Um Conceito Necessário para o Processamento de Demandas de Massa. Revista de Processo, São Paulo: RT, vol. 186, p. 87/107, ago/2010.

CABRAL, Antonio do Passo. A escolha da causa-piloto nos incidentes de resolução de processos repetitivos. Revista de Processo. São Paulo: RT, 2014, v. 231. 
CABRAL, Antonio do Passo. Do incidente de resolução de demandas repetitivas. In: CABRAL, Antonio do Passo; Ronaldo Cramer (Coords.). Comentários ao Novo Código de Processo Civil. $2^{\mathrm{a}}$ ed. Rio de Janeiro: Forense, 2016a.

CABRAL, Antonio do Passo. O novo procedimento-modelo (MusterVerfahren) alemão: uma alternativa às ações coletivas. Revista de Processo, São Paulo: RT, maio/2007, ano 32, n. 147.

CABRAL, Antonio do Passo. Standard-Solution Procedures and Mass Litigation. International Journal of Procedural Law - IAPL, vol. 06, p. 263/281, Intersentia, 2016b.

CADIET, Loïc. Introduction to French Civil Justice System and Civil Procedural Review. Ritsumeikan Law Review, nº 28, 2011.

CAMARGO, Luiz Henrique Volpe. A centralização de processos como etapa necessária do Incidente de Resolução de Demandas Repetitivas. p. 419. Dissertation (Doctoral Program in Civil Procedural Law) - Pontifícia Universidade Católica de São Paulo, São Paulo, 2017. Tutor Prof. Dr. Teresa Arruda Alvim.

COLAÇO ANTUNES, Luis Filipe. A Tutela dos Interesses Difusos em Direito Administrativo: para uma Legitimação Procedimental. Coimbra: Almedina, 1989.

DANTAS, Bruno. Comentários aos arts. 976 a 987. In: WAMBIER, Teresa Arruda Alvim et. al. Breves comentários ao novo Código de Processo Civil. $3^{\mathrm{a}}$ ed. São Paulo: RT, 2017.

DIDIER JR., Fredie. Diretrizes para a compreensão da tutela das causas repetitivas no direito processual civil brasileiro, Lima, Peru.

DIDIER JR., Fredie; BRAGA, Paula Sarno; OLIVEIRA, Rafael. Curso de direito processual civil. Teoria da prova, direito probatório, teoria do precedente, decisão judicial, coisa julgada e antecipação dos efeitos da tutela. 10 a ed. Salvador: Juspodivm, 2015.

DIDIER JR. Fredie; CUNHA, Leonardo Carneiro da (coords.). Grandes temas do novo cpc. Julgamento de Casos Repetitivos. Salvador: JusPodivm, 2017a. v. 10.

DIDIER JR., Fredie; CUNHA, Leonardo Carneiro da. Curso de Direito Processual Civil. 14 ${ }^{\mathrm{a}}$ ed. Salvador: Juspodivm, 2017b, v. 3.

DIDIER JR., Fredie; ZANETI JR., Hermes. Ações coletivas e o incidente de julgamento de casos repetitivos - espécies de processo coletivo no direito brasileiro: aproximações e distinções. Revista de Processo, v. 256, jun./2016, p. 209-218.

DIDIER JR., Fredie; ZANETI JR., Hermes. Curso de Direito Processual. Processo Coletivo. Vol. 4. $11^{\text {a }}$ ed. Salvador: Juspodivm, 2017.

DONZELI, Romolo. L'Azione di Classe a Tutela dei Consumatori. Napoli: Jovene, 2011.

DONZELI, Romolo. La Tutela Giurisdizionale degli Interessi Collettivi. Napoli: Jovene, 2008. 
FERRAND, Frederique. Collective litigation in France: from distrust to cautious admission. In: HARSÁGI, V.; VAN RHEE, C. H. Multi-party Redress Mechanisms in Europe: Squeaking Mice? Cambridge: Intersentia, 2014.

GARNER, Bryan A. (ed.) Black’s Law Dictionary. 9 ed. Thomson Reuters: s.1., 2013.

GIDI, Antonio. Rumo a um Código de Processo Coletivo. A Codificação das Ações Coletivas no Brasil. Rio de Janeiro: Forense, 2008.

GIUSSANI, Andrea. Azioni Collettive Risarcitorie nel Processo Civile. Bologna: Il Mulino, 2008.

GLEEN, H. Patrick. Legal Traditions of the World. $5^{\mathrm{a}}$ ed. Oxford: Oxford University Press, 2014.

HARSÁGI, V.; VAN RHEE, C. H. Multi-party Redress Mechanisms in Europe: Squeaking Mice? Cambridge: Intersentia, 2014.

IRTI, Natalino. L'Età della Decodificazione Vent'Anni Dopo. In: IRTI, Natalino. L'Età della Decodificazione. 4th ed. Milano: Giuffrè, 1999.

MARINONI, Luiz Guilherme. Comentários aos arts. 926 a 928. In: WAMBIER, Teresa Arruda Alvim et. al. Breves comentários ao novo Código de Processo Civil. $2^{\mathrm{a}}$ ed. São Paulo: RT, $2016 \mathrm{a}$.

MARINONI, Luiz Guilherme. Incidente de Resolução de Demandas Repetitivas. Decisão de Questão Idêntica v. Precedente. São Paulo: RT, 2016 b.

MENDES, Aluisio Gonçalves de Castro. Incidente de Resolução de Demandas Repetitivas. Sistematização. Análise e Interpretação do Novo Instituto Processual. Rio de Janeiro:

GEN/Forense, 2017.

MILLER, Arthur R. Of Frankenstein Monsters and Shining Knights: myth, reality, and the "class action problem", Harvard Law Review, vol. 92, issue 3, pp. 664-694, jan. 1979.

MITIDIERO, Daniel. Fundamentação e precedente: dois discursos a partir da decisão judicial. In: Daniel Mitidiero; Guilherme Rizzo Amaral (coords.). Maria Angélica Echer Ferreira Feijó (org.). Processo civil. Estudos em homenagem ao Professor Doutor Carlos Alberto Alvaro de Oliveira. São Paulo: Atlas, 2012, p. 85/99.

MITIDIERO, Daniel. Precedentes. São Paulo: RT, 2016.

SALGADO, José María. Tutela Individual Homogénea. Buenos Aires: Astrea, 2011.

SILVESTRE, Elisabetta. The difficult art of legal transplants: the case of class actions. Revista de Processo, São Paulo: Revista dos Tribunais, vol. 187, p. 99 ss, set. 2010. § 2.

SOUSA, Miguel Teixeira de. A Legitimidade Popular na Tutela dos Interesses Difusos. Lisboa: Lex, 2003.

TEMER, Sophia. Incidente de Resolução de Demandas Repetitivas. Salvador: Juspodivm, 2016. 
VERBIC, Francisco. Processos Colectivos. Buenos Aires: Astrea, 2007.

VOET, Stefaan. 'Where the wild things are' reflections on state and future of European collective redress. Available in: <https://www.academia.edu/31281664/WHERE_THE_WILD_THINGS_ARE_REFLECTIONS _ON_THE_STATE_AND_FUTURE_OF_EUROPEAN_COLLECTIVE_REDRESS >. Access on: mar 032017.

ZANETI JR., Hermes. A Constitucionalização do Processo. O Modelo Constitucional da Justiça Brasileira e as Relações entre Processo e Constituição. 2a ed. São Paulo: Atlas, 2014.

ZANETI JR., Hermes. Comentários ao art. 928. In.: CABRAL, Antonio do Passo; CRAMER, Ronaldo (coords.). Comentários ao Novo Código de Processo Civil. Rio de Janeiro: Forense, 2015, p. 1.332/1.338.

ZANETI JR., Hermes. O Valor Vinculante dos Precedentes. $3^{\mathrm{a}}$ ed. Salvador: Juspodivm, 2017. 